\title{
Peningkatan Kesejahteraan Masyarakat Kawula Muda Kota Surabaya Melalui GIBEI STIESIA Surabaya
}

\author{
Bambang Hadi Santoso ${ }^{1 *}$, Yayah Atmajawati ${ }^{2}$, Sasi Agustin ${ }^{3}$ \\ 1,2,3Sekolah Tinggi Ilmu Ekonomi Indonesia (STIESIA) Surabaya \\ e-mail: bambanghadisantoso@stiesia.ac.id ${ }^{1}{ }_{\text {Lyayah@stiesia.ac.id }}^{2}{ }_{2}$ sasiagustin@stiesia.ac.id $^{3}$ \\ *Penulis Korespondensi: E-mail: bambanghadisantoso@stiesia.ac.id ${ }^{1}$
}

\begin{abstract}
Through the program of "The Increase of Youngster Society of Surabaya City via GIBEI STIESIA Surabaya", it can be increased total number of opening account (OA) in Surabaya, so it can add total investor in Surabaya in capital market in Indonesia. Total number of OA in Surabaya is very limited, only $1.119 \%$ of total population in Surabaya. Such condition influences on partnership GIBEI STIESIA - i.e. it is not easy to obtained local investor to increase the performance of GIBEI STIESIA. The solution will be done by conducting capital market socialization and education addressed to the society, mainly the youngsters (student of university and student of senior high school). This is necessary for the youngsters the understanding in capital market since they were young, so when they pass from the senior high school or university, they will be ready to invest their money in capital market. After they know capital market, finally they are aware its benefit, and therefore they decide to invest money in capital market in order to obtain welfare. The more the public invest in capital market it will achieve the public welfare, and also the capital market industry in Indonesia becomes great and equivalent with the capital market in the Asia - Pacific. Output of this activity: total number of OA of the public in Surabaya, mainly students, so it will increase the GIBEI STIESIA performance. Outcome: the welfare of the public in Surabaya increases by executing the above mentioned investment, in other words the public in Surabaya contributes the capital market industry especially in Surabaya.
\end{abstract}

Keywords: investor, opening account, capital market, public welfare

\begin{abstract}
Abstrak
Melalui Program "Peningkatan Kesejahteraan Masyarakat Kawula Muda Kota Surabaya Melalui GIBEI STIESIA Surabaya” dapat ditingkatkan jumlah kepemilikan Rekening Efek (RE) di Surabaya, sehingga terdapat penambahan jumlah pemodal Surabaya yang turut serta meramaikan pasar modal Indonesia. Jumlah pemilik RE Surabaya sangatlah kecil, 1,119 \% dari jumlah penduduk Surabaya. Kondisi tersebut berdampak pada mitra kerja: GIBEI STIESIA-tidak mudahnya mendapatkan pemodal lokal yang berpengaruh pada kinerja GIBEI STIESIA. Permasalahan diselesaikan dengan memberikan sosialisasi \& edukasi pasar modal kepada masyarakat umum, terutama kawula muda (mahasiswa, pelajar). Kepada mereka diperlukan pemahaman sejak dini, sehingga saat mereka terjun ke masyarakat, siap melakukan investasi pasar modal. Setelah mengenali pasar modal, mereka akhirnya menyadari manfaatnya, sehingga akhirnya bersedia melakukan investasi pasar modal untuk mendapatkan kesejahteraan. Semakin banyak masyarakat melakukan investasi pasar modal, akan tercapai kesejahteraan masyarakat, di samping itu industri pasar modal Indonesia menjadi semakin besar untuk disetarakan pasar modal Asia Pasifik. Output kegiatan: bertambahnya jumlah RE masyarakat Surabaya, khususnya kalangan mahasiswa pelajar, sehingga dapat menaikkan kinerja GIBEI STIESIA. Outcome: semakin sejahteranya masyarakat Surabaya dengan melakukan investasi dimaksud, serta dapat dikatakan masyarakat Surabaya berkontribusi dalam menyemarakkan industri pasar modal, khususnya Surabaya.
\end{abstract}

Kata kunci: Pemodal, Rekening Efek, pasar modal, kesejahteraaan masyarakat. 


\section{PENDAHULUAN}

\subsection{Analisis Situasi}

\section{Latar Belakang}

Sejak tahun 1977 pasar modal di Indonesia diaktifkan kembali setelah mengalami vakum yang cukup lama. Karena mengalami vakum, maka pemahaman pasar modal pada masyarakat Indonesia belumlah seperti yang diharapkan, atau dapat dikatakan bahwa literasi masyarakat tentang pasar modal masih rendah (Dwidjosumarno, 2017).

Hal tersebut antara lain ditunjukkan oleh jumlah pemilik RE (Rekening Efek) di Kota Surabaya yang sangat kecil, yakni hanya sebanyak 31.718 penduduk (Dwidjosumarno, Nopember 2017), dan sementara itu jumlah penduduk Kota Surabaya per akhir tahun 2014 adalah sebanyak 2.833.924 orang (Jawa Timur dalam Angka, 2014), yang dengan demikian jumlah pemilik RE di Kota Surabaya hanya 1,119 \% saja dari jumlah penduduk Kota Surabaya (Dwidjosumarno, Nopember 2017). Kondisi tersebut berdampak pada mitra kerja "GIBEI STIESIA Surabaya (Galeri Investasi Bursa Efek Indonesia - Sekolah Tinggi Ilmu Ekonomi Indonesia - Surabaya)", yaitu tidak mudahnya mendapatkan pemodal (investor) lokal yang akhirnya berpengaruh pada kinerja GIBEI STIESIA Surabaya. PT Bursa Efek Indonesia meminta GIBEI STIESIA Surabaya untuk setidaknya di setiap tahun terdapat minimal 100 pembukaan RE serta dituntut adanya nilai transaksi perdagangan efek.

Sejauh ini masyarakat lebih mengenal serta memahami industri perbankan dan bukan pasar modal. Perusahaan-perusahaan dalam memenuhi kebutuhan sumber pendanaan juga lebih memilih mendapatkan sumber pendanaan melalui perbankan, dan demikian pula masyarakat pemilik modal (investor) lebih memilih melakukan investasi (baca: menyimpan uangnya) melalui perbankan dalam bentuk deposito.

Padahal pasar modal sebenarnya dapat dipakai sebagai alternatif bagi masyarakat pemodal untuk melakukan investasi, dan di samping itu pasar modal juga sebagai alternatif untuk mendapatkan pendanaan bagi perusahaan-perusahaan yang membutuhkan dana.

Padahal sebenarnya masyarakat dengan menanamkan dananya dalam bentuk deposito, hanya mendapatkan return (keuntungan) dalam jumlah yang tidak seberapa (saat ini berkisar $4 \%$ per tahun). Sedangkan masyarakat yang melakukan investasi di pasar modal, mendapatkan return dalam jumlah yang lebih besar dari itu. Return investasi pada saham dapat berupa pembagian deviden dari perusahaan kepada masyarakat pemodal, selain berupa capital gain. Deviden adalah merupakan sebagian dari keuntungan (profit) perusahaan yang diberikan kepada masyarakat pemodal selaku pemilik saham dalam bentuk uang tunai (cash dividend), sedangkan capital gain adalah keuntungan yang didapat masyarakat pemodal yang berasal dari menjual saham pada harga yang lebih tinggi jika dibandingkan dengan harga saham pada saat mereka membeli saham pada pertama kalinya. Sementara itu, bagi perusahaan-perusahaan, pasar modal merupakan sarana untuk mendapatkan sumber pendanaan di luar perbankan, yang malahan tidak memberatkan bagi mereka, dikarenakan mereka tidak perlu melakukan pembayaran bunga pinjaman sehubungan dengan pinjaman dana bank.

Pemahaman atau literasi mengenai hal - hal tersebut (manfaat dan pentingnya keberadaan pasar modal), baik bagi masyakarat pemilik modal maupun bagi perusahaanperusahaan, perlu diketahui oleh seluruh lapisan masyarakat melalui kegiatan sosialisasi \& edukasi pasar modal, tidak terkecuali para kawula muda (mahasiswa dan pelajar). Pada saat 
literasi mengenai pasar modal telah terbentuk di masyarakat, maka masyarakat menjadi berkenan untuk melakukan investasi di pasar modal, yang ditandai dengan kesediaan melakukan pembukaan RE, yang pada akhirnya masyarakat menjadi sejahtera dengan melakukan investasi di pasar modal. Kegiatan peningkatan literasi pasar modal pada masyarakat dapat dilakukan oleh GIBEI STIESIA Surabaya.

\section{Gambaran Mitra Kerja}

Mitra kerja dari kegiatan pengabdian masyarakat ini adalah GIBEI STIESIA Surabaya. GIBEI STIESIA Surabaya adalah merupakan salah satu GIBEI yang ada di Surabaya yang dalam menjalankan aktivitasnya diperlukan kolaborasi dengan PT Bursa Efek Indonesia dan PT Reliance Securities Indonesia Tbk. GIBEI ada banyak terdapat di kampus - kampus, yang keberadaannya diperlukan dalam rangka untuk melakukan sosialisasi \& edukasi pasar modal di lingkungan sivitas akademika dan publik sebagai upaya untuk mendapatkan pemodal (investor) lokal yang nantinya akan dapat meramaikan pasar modal Indonesia. Maka dengan demikian, GIBEI STIESIA Surabaya dituntut kinerjanya oleh PT Bursa Efek Indonesia, yang di antaranya mencakup:

- Memberikan sosialisasi \& edukasi pasar modal untuk meningkatkan literasi tentang pasar modal di kalangan masyarakat.

- Meningkatkan jumlah kepemilikan RE (Rekening Efek) yang dengan demikian menambah jumlah pemodal (lokal) di pasar modal Indonesia.

- Meningkatkan jumlah nilai transaksi perdagangan efek melalui GIBEI STIESIA Surabaya.

- Meningkatkan perolehan transaction fee pada GIBEI STIESIA Surabaya dan PT Reliance Securities Indonesia Tbk selaku mitra kerja GIBEI STIESIA Surabaya.

Berikut ini gambar peta lokasi mitra kerja "GIBEI STIESIA Surabaya":

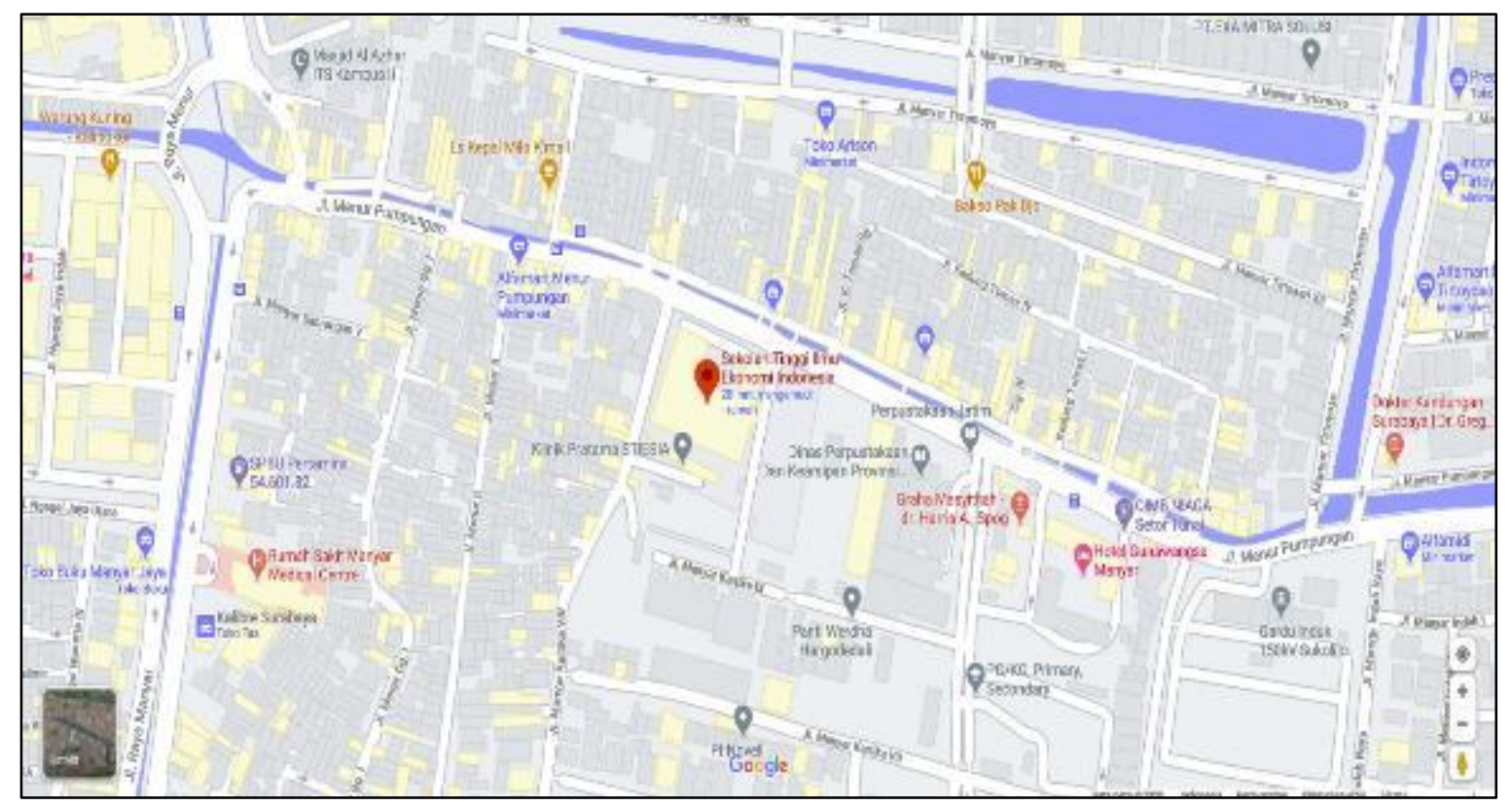

Gambar 1. Peta Lokasi GIBEI STIESIA Sumber: Google Maps

Sedangkan di bawah ini kantor GIBEI STIESIA Surabaya di Jalan Menur Pumpungan No. 30 - Surabaya, yang lokasinya menjadi satu dengan kampus STIESIA Surabaya. 


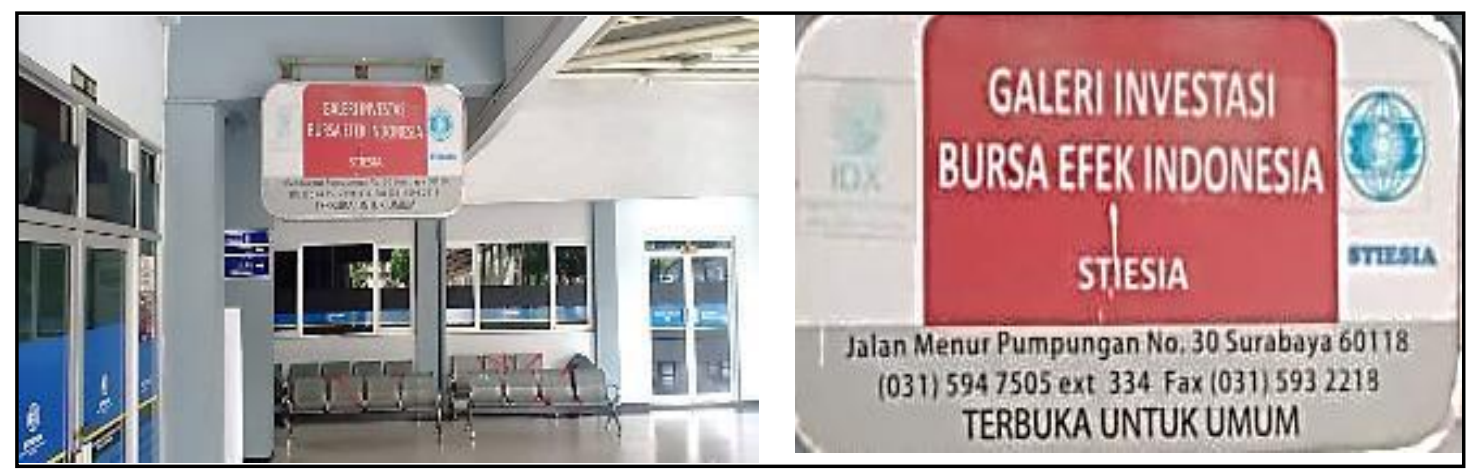

Gambar 2. Kantor GIBEI STIESIA

Sumber: Dokumentasi GIBEI STIESIA

Berikut ini adalah situasi/suasana jual dan beli efek sejumlah mahasiswa di ruang perdagangan (trading room) GIBEI STIESIA Surabaya dan diskusi antara pialang (broker) dengan mahasiswa untuk membantu membuat keputusan jual dan beli efek:

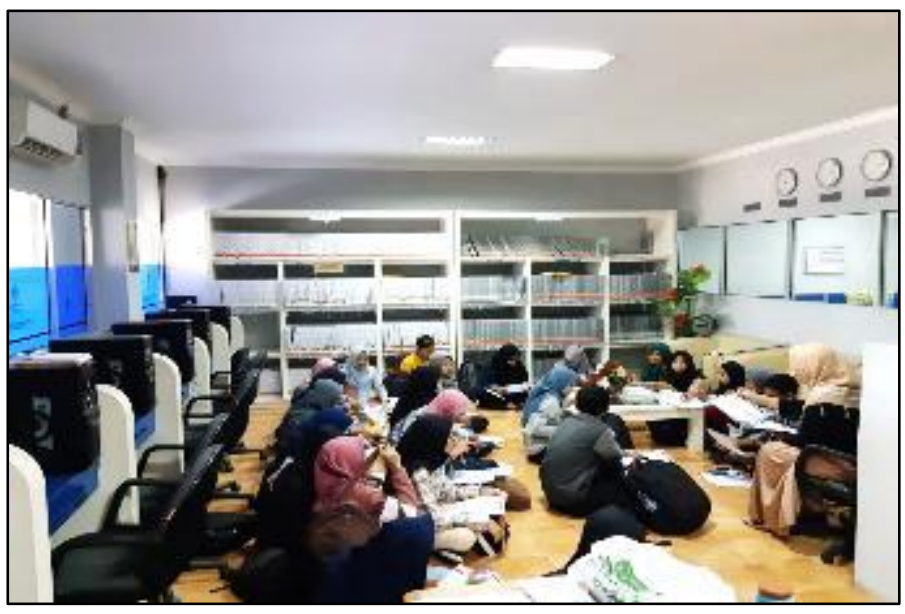

Gambar 3. Situasi Jual/Beli Efek oleh Mahasiswa (Sumber: Dokumentasi GIBEI STIESIA)

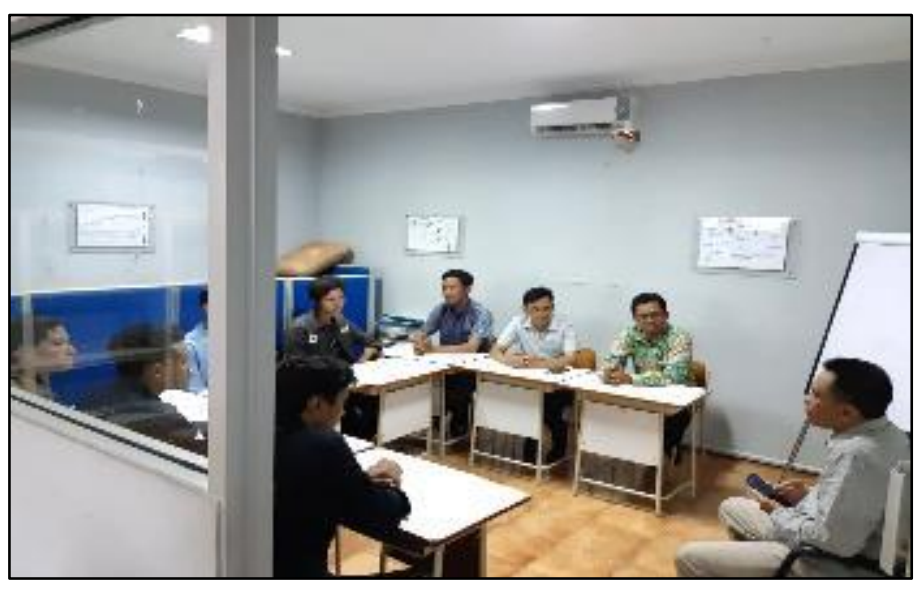

Gambar 4. Diskusi antara Pialang dengan Mahasiswa (Sumber: Dokumentasi GIBEI STIESIA) 


\subsection{Tujuan Pengabdian Kepada Masyarakat (PKM)}

Tujuan dilaksanakannya PKM Peningkatan Kesejahteraan Masyarakat Kawula Muda Kota Surabaya Melalui GIBEI STIESIA Surabaya dapat disebutkan sebagai berikut:

- Mengetahui sampai seberapa jauh masyarakat kawula muda Surabaya berniat berinvestasi di pasar modal.

- Memberikan pemahaman kepada masyarakat kawula muda Surabaya tentang pasar modal dan manfaat berinvestasi di pasar modal, serta tatacara dan strategi berinvestasi di pasar modal melalui kegiatan sosialisasi \& edukasi.

- Menambah jumlah masyarakat kawula muda Surabaya yang bersedia melakukan pembukaan Rekening Efek, yang merupakan bukti bahwa mereka telah menjadi pemodal di pasar modal, setelah mereka memiliki literasi yang cukup tentang pasar modal dan investasi pada instrumen investasi pasar modal.

- Meramaikan pasar modal Indonesia karena bertambahnya jumlah Rekening Efek (jumlah pemodal) dan jumlah transaksi perdagangan efek di pasar modal Indonesia, khususnya Surabaya.

Dengan hal - hal tersebut di atas, diharapkan:

- Terbentuk/terkembangkannya sekelompok masyarakat muda yang mandiri, baik secara ekonomi dan sosial.

- Terciptanya ketenteraman dan kenyamanan dalam kehidupan bermasyarakat, khususnya masyarakat kawula muda, serta diharapkan dapat meningkatkan berbagai macam keterampilan, terutama keterampilan berfikir, dan bahkan keterampilan lainnya yang sangat diperlukan oleh masyarakat kawula muda, baik keterampilan yang berbentuk hard skill maupun softskill.

\subsection{Permasalahan Mitra}

Mitra dari kegiatan PKM ini adalah GIBEI STIESIA Surabaya. Permasalahan mitra adalah tidak mudahnya untuk mendapatkan pemodal, disebabkan masih terbatasnya literasi/pemahaman dari masyarakat mengenai pasar modal dan investasi di bidang pasar modal, yang mengakibatkan menjadi terbatasnya jumlah masyarakat yang bersedia membuka Rekening Efek sebagai tanda/bukti bahwa masyarakat telah menjadi pemodal di pasar modal Indonesia. Terbatasnya jumlah Rekening Efek juga membawa pengaruh pada jumlah nilai transaksi perdagangan efek melalui GIBEI STIESIA Surabaya.

\section{METODE PELAKSANAAN}

Berisi deskripsi tentang proses perencanaan aksi bersama masyarakat (mitra).

\subsection{Metode Pelaksanaan}

Secara umum metode pelaksanaan dapat dilakukan sebagai berikut:

Memberikan pemahaman kepada masyarakat kawula muda (mahasiswa dan pelajar) melalui kegiatan sosialisasi \& edukasi di bidang keuangan dan investasi di pasar modal sampai mereka bersedia untuk melakukan pembukaan Rekening Efek yang merupakan sarana untuk berinvestasi di pasar modal, yang apabila digambarkan dalam bentuk bagan alir sebagai berikut: 


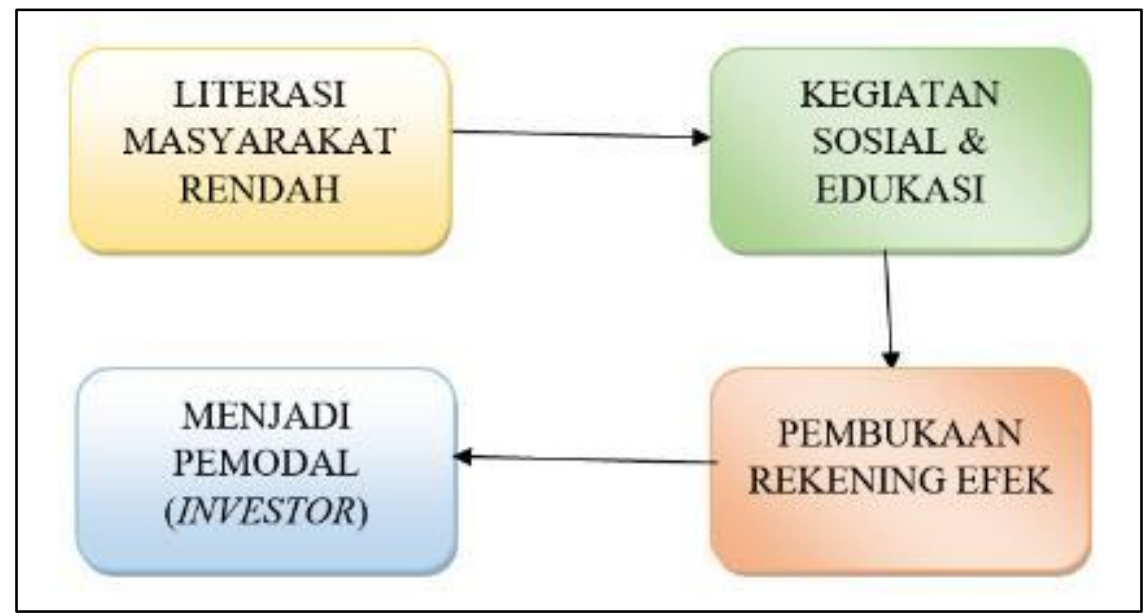

Gambar 5. Bagan Alir Metode Pelaksanaan

(Sumber: Dikembangkan oleh Tim Pengabdian Kepada Masyarakat)

Metode pelaksanaan Kegiatan Pengabdian Kepada Masyarakat yang berupa "Peningkatan Kesejahteraan Masyarakat Kawula Muda Kota Surabaya Melalui GIBEI STIESIA Surabaya" mengikuti run down yang terdapat pada tabel berikut ini:

Tabel 1. Metode Pelaksanaan

\begin{tabular}{|c|c|c|}
\hline No & Kegiatan & Keterangan \\
\hline 1 & Penyusunan prososal PKM & Cukup jelas \\
\hline 2 & $\begin{array}{l}\text { Pendekatan ke GIBEI STIESIA } \\
\text { Surabaya dan masyarakat } \\
\text { kawula muda (mahasiswa dan } \\
\text { pelajar ke kampus - kampus dan } \\
\text { sekolah - sekolah) }\end{array}$ & $\begin{array}{l}\text { Melakukan courtesy call, kontak - } \\
\text { kontak dan/atau surat menyurat }\end{array}$ \\
\hline 3 & Observasi lapangan & $\begin{array}{l}\text { Melakukan peninjauan lapangan } \\
\text { ke GIBEI STIESIA Surabaya } \\
\text { (selaku mitra kerja) serta } \\
\text { masyarakat kawula muda } \\
\text { (mahasiswa dan pelajar di } \\
\text { kampus - kampus dan sekolah - } \\
\text { sekolah) }\end{array}$ \\
\hline 4 & Pelaksanaan kegiatan PKM & $\begin{array}{l}\text { Melakukan kegiatan PKM kepada } \\
\text { masyarakat kawula muda } \\
\text { (mahasiswa dan pelajar) di Kota } \\
\text { Surabaya }\end{array}$ \\
\hline 5 & Penyiapan draft laporan PKM & Cukup jelas \\
\hline 6 & Penyiapan laporan akhir PKM & Cukup jelas \\
\hline
\end{tabular}

Sumber: Tim Pengabdian Kepada Masyarakat

\subsection{Partisipasi Mitra}

Partisipasi mitra kerja "GIBEI STIESIA Surabaya” dalam pelaksanaan program adalah sebagai berikut: 
- Menghubungi masyarakat kawula muda (mahasiswa dan pelajar) untuk menawarkan kegiatan sosialisasi \& edukasi mengenai pasar modal dan investasi di pasar modal.

- Menyediakan program aplikasi perdagangan untuk melakukan transaksi jual dan beli instrumen investasi di pasar modal.

- Melakukan sosialisasi \& edukasi pasar modal dan investasi di pasar modal (teori) yang dilanjutkan dengan melakukan pelatihan simulasi transaksi jual dan beli instrumen investasi pasar modal dengan menggunakan program aplikasi perdagangan kepada masyarakat kawula muda (mahasiswa dan pelajar).

- Membantu pelaksanaan pembukaan Rekening Efek (persiapan dokumen dan pengisian formulir aplikasi pembukaan Rekening Efek).

- Pelayanan pasca pembukaan Rekening Efek, yaitu pada saat pemodal telah memiliki Rekening Efek dan mulai melakukan (mengaplikasikan) transaksi jual dan beli instrumen investasi pasar modal, maka GIBEI STIESIA Surabaya bersama - sama dengan PT Reliance Securities Indonesia Tbk membantu mengarahkan para pemodal kawula muda (mahasiswa dan pelajar) dalam melaksanakan keputusan jual dan beli instrumen investasi pasar modal tersebut.

Partisipasi mitra kerja tentunya harus diikuti dengan hal - hal berikut ini:

- Masyarakat kawula muda (mahasiswa dan pelajar) mendukung pelaksanaan sosialisasi \& edukasi yang ditawarkan GIBEI STIESIA Surabaya bekerjasama dengan PT Reliance Securities Indonesia Tbk dengan menghadiri kegiatan tersebut, baik secara on line dan/atau off line.

- Masyarakat kawula muda (mahasiswa dan pelajar) bersedia melakukan pembukaan Rekening Efek sebagai bukti bahwa mereka telah bersedia menjadi pemodal di pasar modal Indonesia.

- Masyarakat kawula muda (mahasiswa dan pelajar) bersedia menjadi pemodal yang aktif di pasar modal Indonesia.

\subsection{Evaluasi}

Evaluasi pelaksanaan program dan keberlanjutan program di lapangan setelah kegiatan PKM selesai dilaksanakan dapat dijabarkan sebagai berikut:

- Setelah berakhirnya kegiatan PKM ini, dilakukan evaluasi yang terutama menyangkut keefektifan/keberhasilan PKM, terutama efektivitas dari kegiatan perdagangan instrumen investasi pasar modal pada GIBEI STIESIA Surabaya.

- Setelah dinyatakan efektif berdasarkan pengamatan, akan diteruskan dengan melakukan kegiatan sosialisasi \& edukasi pada masyarakat di luar mahasiswa dan pelajar, misalnya masyarakat dalam asosiasi profesi, seperti Asosiasi Dosen Republik Indonesia (ADRI), dan asosiasi profesi yang lain, semisal Ikatan Notaris Indonesia (INI).

- Melakukan kegiatan sosialisasi \& edukasi pada kota - kota lain di luar kota Surabaya.

\subsection{Jadwal Pelaksanaan PKM}

Kegiatan PKM "Peningkatan Kesejahteraan Masyarakat Kawula Muda Kota Surabaya melalui GIBEI STIESIA Surabaya" berlangsung selama 9 bulan, dengan jadwal seperti dapat dilihat pada Tabel: Jadwal Kegiatan Pengabdian Kepada Masyarakat. Setelah berakhirnya penyusunan proposal, kegiatan dimulai pada sekitar bulan Maret 2019 (selama 9 bulan, jadi terjadwal sampai dengan bulan Desember 2019), yang rincian jadwalnya dapat dilihat pada tabel berikut: 
Tabel 2. Jadwal Kegiatan Pengabdian Kepada Masyarakat

\begin{tabular}{|c|c|c|c|c|c|c|c|c|}
\hline Nama Kegiatan & $\begin{array}{c}\text { Bulan } \\
1,2\end{array}$ & $\begin{array}{c}\text { Bulan } \\
3,4\end{array}$ & $\begin{array}{c}\text { Bulan } \\
5,6\end{array}$ & $\begin{array}{c}\text { Bulan } \\
7,8\end{array}$ & $\begin{array}{c}\text { Bulan } \\
9\end{array}$ & $\begin{array}{c}\text { Bulan } \\
10\end{array}$ & $\begin{array}{c}\text { Bulan } \\
11\end{array}$ & $\begin{array}{c}\text { Bulan } \\
12\end{array}$ \\
\hline 1. Proposal & & & & & & & & \\
\hline $\begin{array}{l}\text { 2. Courtesy Call ke } \\
\text { Mitra Kerja } \\
\text { dan ke Kampus } \\
\text { - kampus serta } \\
\text { ke Sekolah - } \\
\text { sekolah } \\
\text { Tingkat SMA } \\
\text { (Sekolah } \\
\text { Menengah } \\
\text { Atas) }\end{array}$ & & & & & & & & \\
\hline 3. Observasi & & & & & & & & \\
\hline $\begin{array}{l}\text { 4. Pelaksanaan } \\
\text { Sosialisasi \& } \\
\text { Edukasi }\end{array}$ & & & & & & & & \\
\hline 5. Draft Laporan & & & & & & & & \\
\hline $\begin{array}{l}\text { 6. Laporan Akhir } \\
\text { (Final) }\end{array}$ & & & & & & & & \\
\hline
\end{tabular}

Sumber: Tim Pengabdian Kepada Masyarakat

\section{HASIL dan PEMBAHASAN}

Setelah berakhirnya kegiatan sosialisasi \& edukasi pasar modal dan investasi di pasar modal yang diikuti oleh mahasiswa dan pelajar sebagai kelompok masyarakat kawula muda, maka pada akhirnya mereka bersedia membuka Rekening Efek, sehingga sampai pada akhirnya mahasiswa dan pelajar dapat melakukan transaksi jual dan beli efek dengan nilai transaksi perdagangan efek (GIBEI STIESIA Surabaya, Pebruari, Maret, April, Mei, Juni, Juli, September, Nopember, Desember, 2019) sebagaimana dapat dilihat pada tabel berikut ini:

Tabel 3. Nilai Transaksi Perdagangan Efek

\begin{tabular}{cc}
\hline Bulan \& Tahun & $\begin{array}{c}\text { Jumlah Nilai Transaksi } \\
\text { (dalam Rupiah) }\end{array}$ \\
\hline Januari 2019 & 40.312 .400 \\
Pebruari 2019 & 2.623 .800 \\
Maret 2019 & 33.308 .300 \\
April 2019 & 105.074 .000 \\
Mei 2019 & 215.206 .200 \\
Juni 2019 & 386.867 .700 \\
Juli 2019 & 644.163 .900 \\
Agustus & 201.173 .500 \\
\hline
\end{tabular}




\begin{tabular}{cc}
\hline Bulan \& Tahun & $\begin{array}{c}\text { Jumlah Nilai Transaksi } \\
\text { (dalam Rupiah) }\end{array}$ \\
\hline September 2019 & 282.295 .000 \\
Oktober 2019 & 163.763 .300 \\
Nopember 2019 & Tidak tersedia data \\
Desember 2019 & 9.281 .200 \\
\hline
\end{tabular}

(Sumber: GIBEI STIESIA Surabaya \& PT Reliance Securities Indonresia Tbk)

Dari tabel di atas nampak bahwa setelah dilakukannya kegiatan sosialisasi \& edukasi, maka terjadi penambahan jumlah kepemilikan Rekening Efek dari masyarakat pemodal, khususnya dari kalangan mahasiswa dan pelajar. Dengan demikian pada akhirnya terjadi penambahan nilai transaksi perdagangan efek, yang nampak perkembangannya dari waktu ke waktu (dari bulan ke bulan) selama tahun 2019 yang mengalami kenaikan. Pada bulan Maret 2019, terjadi kenaikan nilai transaksi dari sebesar Rp. 2.623 .800 pada bulan Pebruari 2019 (GIBEI STIESIA Surabaya, Pebruari 2019) menjadi sebesar Rp. 105.074.000 (GIBEI STIESIA Surabaya, Maret 2019) dan kemudian mengalami kenaikan dengan sangat signifikan pada bulan - bulan Mei, Juni dan Juli 2019, masing - masing sebesar Rp. 215.206.200 (GIBEI STIESIA Surabaya, Mei 2019), Rp. 386.867 .700 (GIBEI STIESIA Surabaya, Juni 2019), dan Rp. 644.163.900 (GIBEI STIESIA Surabaya, Juli 2019).

Sedangkan tabel berikut menunjukkan jumlah peserta sosialisasi dan edukasi yang pernah dilakukan mulai Maret 2019 sampai dengan Desember 2019 yang pada akhirnya membuahkan hasil terealisasinya pembukaan Rekening Efek dan nilai transaksi perdagangan efek yang semakin meningkat.

Tabel 4. Jumlah Peserta Sosialisasi \& Edukasi Maret 2019 - Desember 2019

\begin{tabular}{|c|c|c|}
\hline $\begin{array}{c}\text { Tanggal, Bulan \& } \\
\text { Tahun }\end{array}$ & Sosialisasi \& Edukasi & Jumlah Peserta \\
\hline 4 Desember 2019 & Sekolah Pasar Modal & 14 \\
\hline 9 Desember 2019 & Seminar Pasar Modal & 98 \\
\hline 11 Desember 2019 & Sekolah Pasar Modal & 55 \\
\hline 13 Desember 2019 & Seminar Pasar Modal & 18 \\
\hline 18 Desember 2019 & Sekolah Pasar Modal & 20 \\
\hline 27 Desember 2019 & Sekolah Pasar Modal & 7 \\
\hline 6 Nopember 2019 & Sekolah Pasar Modal & 7 \\
\hline 13 Nopember 2019 & Sekolah Pasar Modal & 10 \\
\hline 20 Nopember 2019 & Sekolah Pasar Modal & 11 \\
\hline 27 Nopember 2019 & Sekolah Pasar Modal & 11 \\
\hline 16 September 2019 & Sekolah Pasar Modal & 4 \\
\hline 18 September 2019 & Sekolah Pasar Modal & 6 \\
\hline 23 September 2019 & Sekolah Pasar Modal & 75 \\
\hline 25 September 2019 & Sekolah Pasar Modal & 80 \\
\hline 12 April 2019 & Seminar Pasar Modal & $\mathbf{4 3 3 ~ p e s e r t a ~}$ \\
\hline 27 Maret 2019 & Beli Saham Bareng - bareng & \\
\hline Jumlah: & & \\
\hline
\end{tabular}

(Sumber: GIBEI STIESIA Surabaya)

Dengan jumlah peserta sejumlah 433 peserta yang hampir ke semuanya bersedia melakukan pembukaan Rekening Efek, sangat mendorong jumlah nilai transaksi 
perdagangan efek di GIBEI STIESIA Surabaya, seperti terlihat pada tabel sebelumnya (Tabel: Nilai Transaksi Perdagangan Efek), sedangkan pada tahun lalu jumlah peserta sosialisasi dan edukasi hanya sebesar 125 peserta (artinya terjadi peningkatan lebih dari 2 $\mathrm{x}$ lipat pada tahun 2019).

Dokumentasi berikut menunjukkan berbagai kegiatan sosialisasi \& edukasi yang ditujukan kepada masyarakat kawula muda (mahasiswa dan pelajar), di antaranya mahasiswa dari Sekolah Tinggi Ilmu Ekonomi Indonesia (STIESIA) Surabaya, mahasiswa dari Prodi Statistik Bisnis ITS (Institut Teknologi Sepuluh Nopember) Surabaya, dan pelajar SMK Muhammadiyah 1 di Surabaya. Kegiatan tersebut dilakukan secara off line (sebelum terjadi pandemi covid 19) dan secara on line (setelah terjadinya pandemi covid 19).

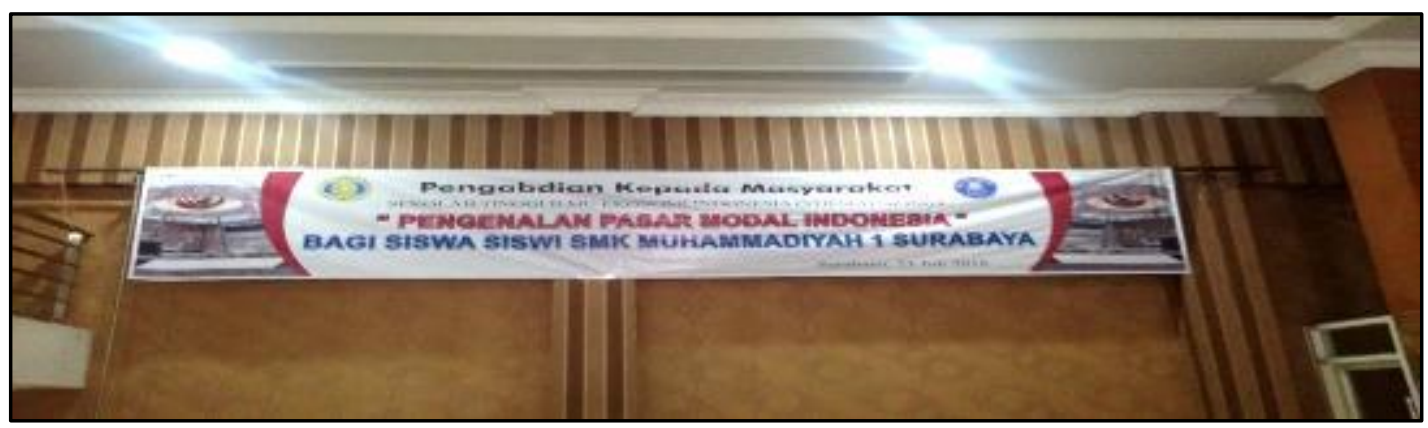

Gambar 6. Spanduk Pengabdian Kepada Masyarakat untuk Pelajar SMK (Sumber: Dokumentasi GIBEI STIESIA)

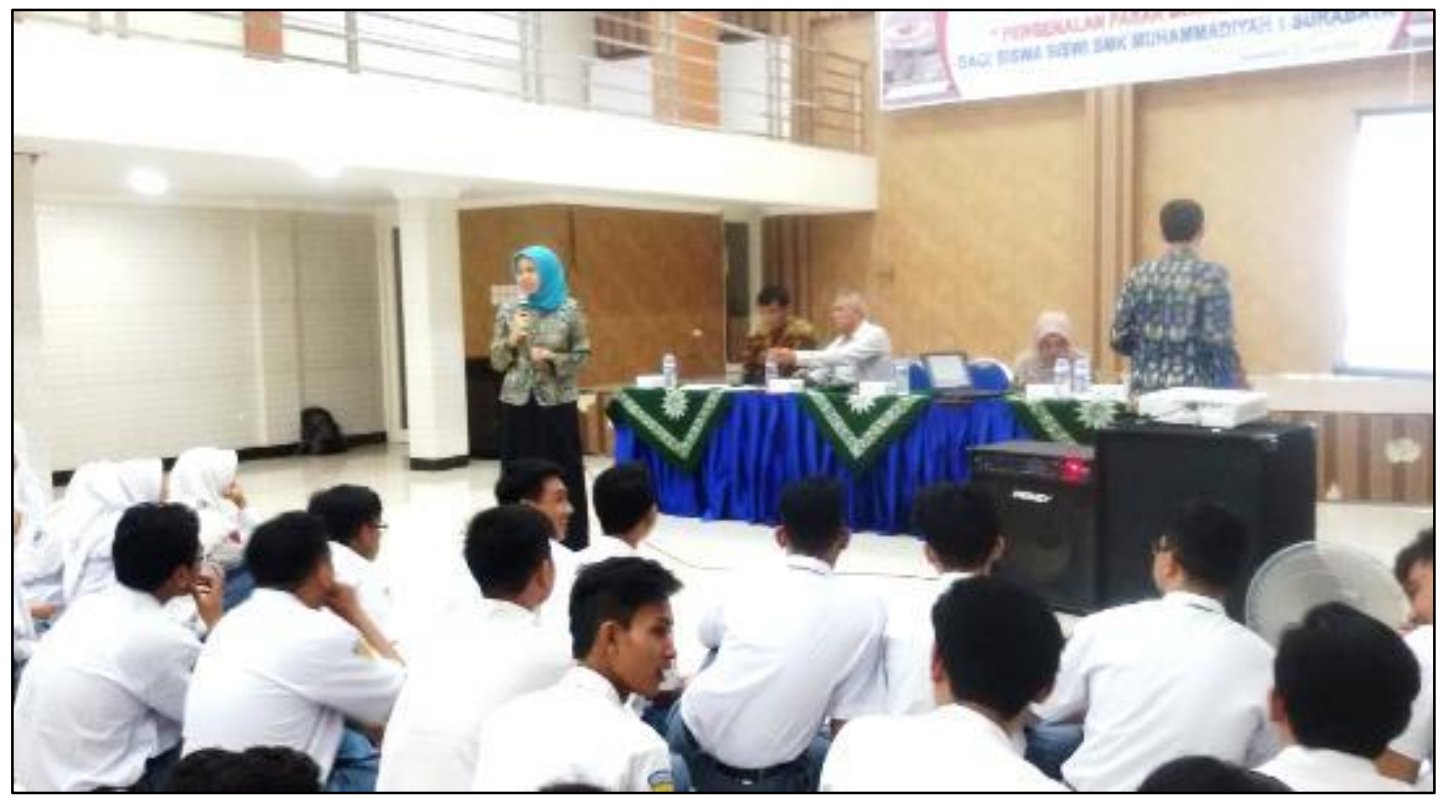

Gambar 7. Sosialisasi dan Edukasi kepada Pelajar SMK

(Sumber: Dokumentasi GIBEI STIESIA) 


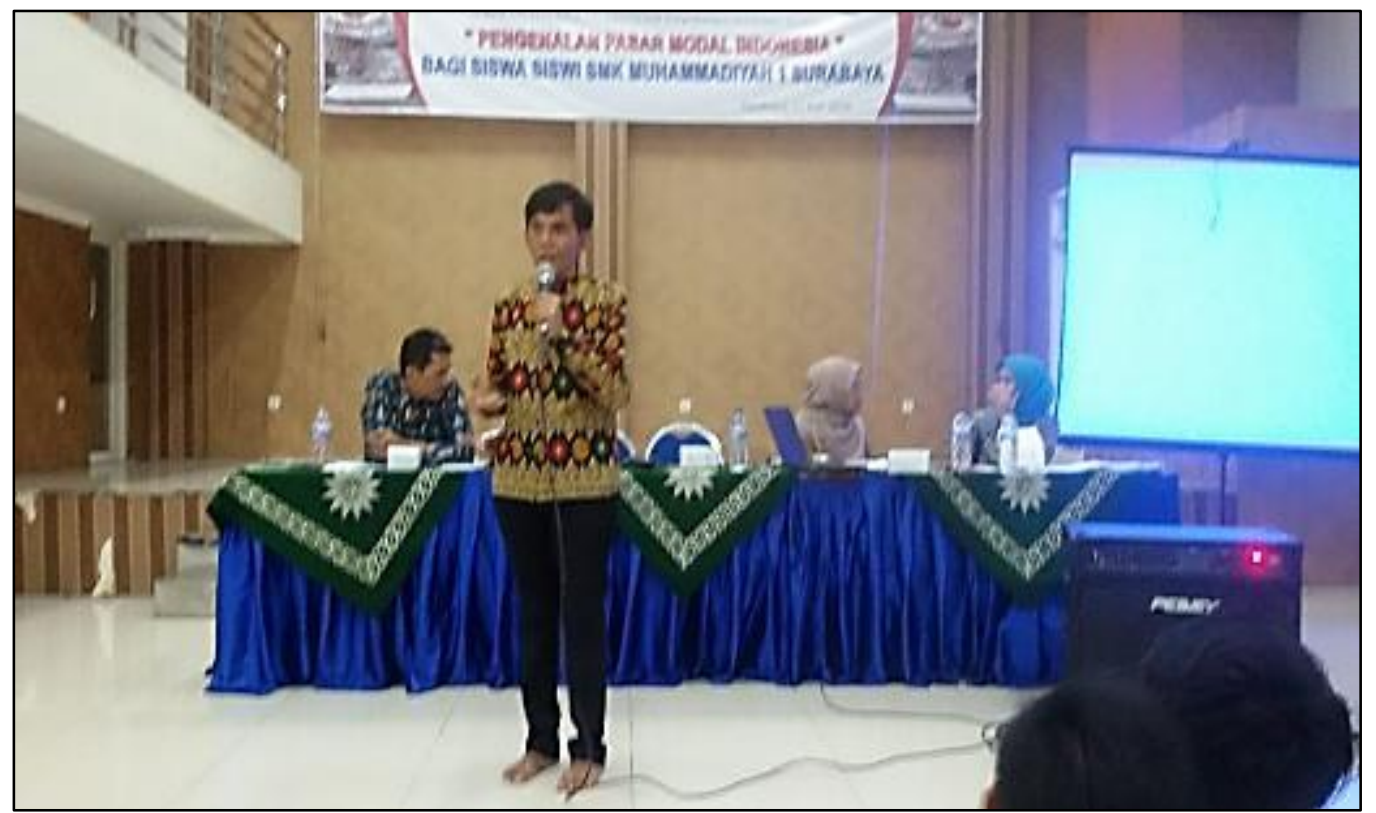

Gambar 8. Pemberian Materi kepada Pelajar SMK

(Sumber: Dokumentasi GIBEI STIESIA)

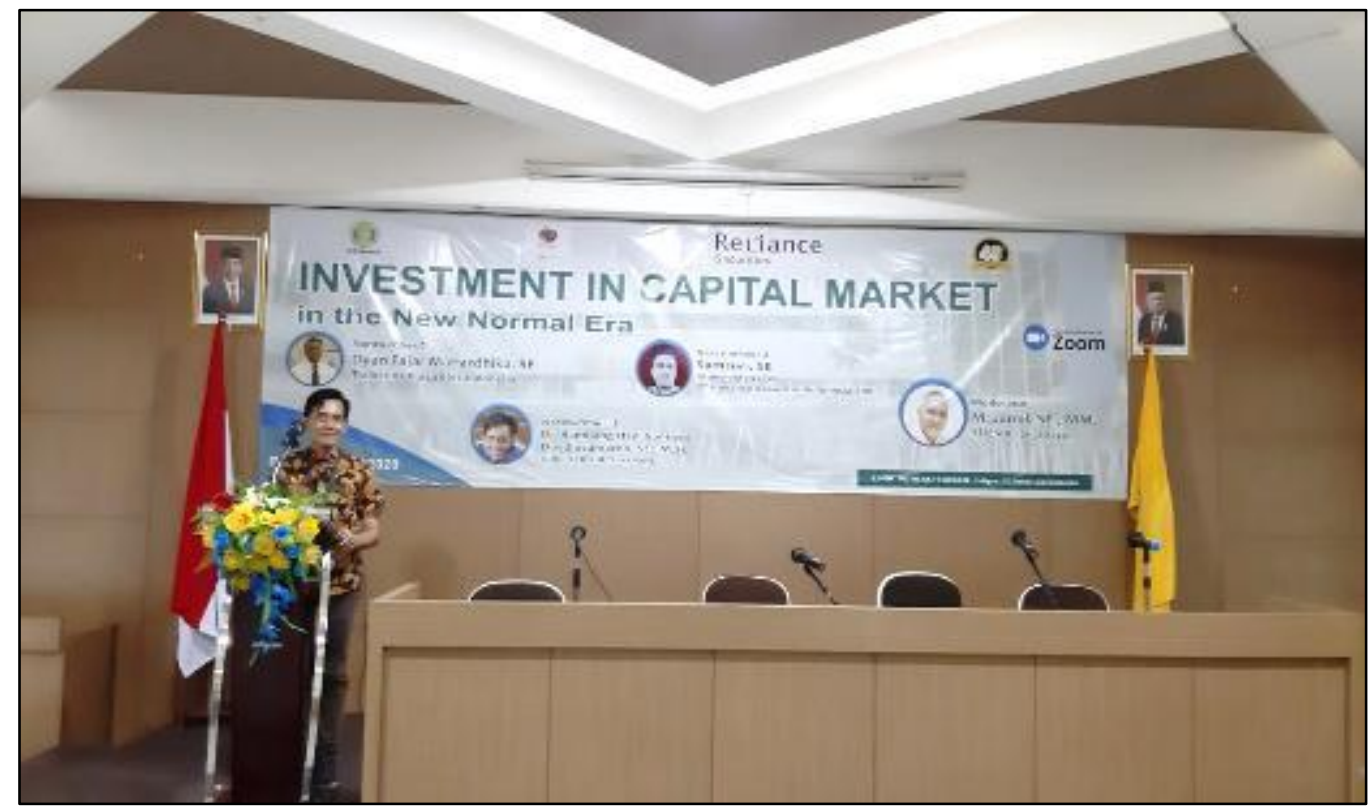

Gambar 9. Pemberian Materi secara Online untuk Peserta Umum (Sumber: Dokumentasi GIBEI STIESIA) 


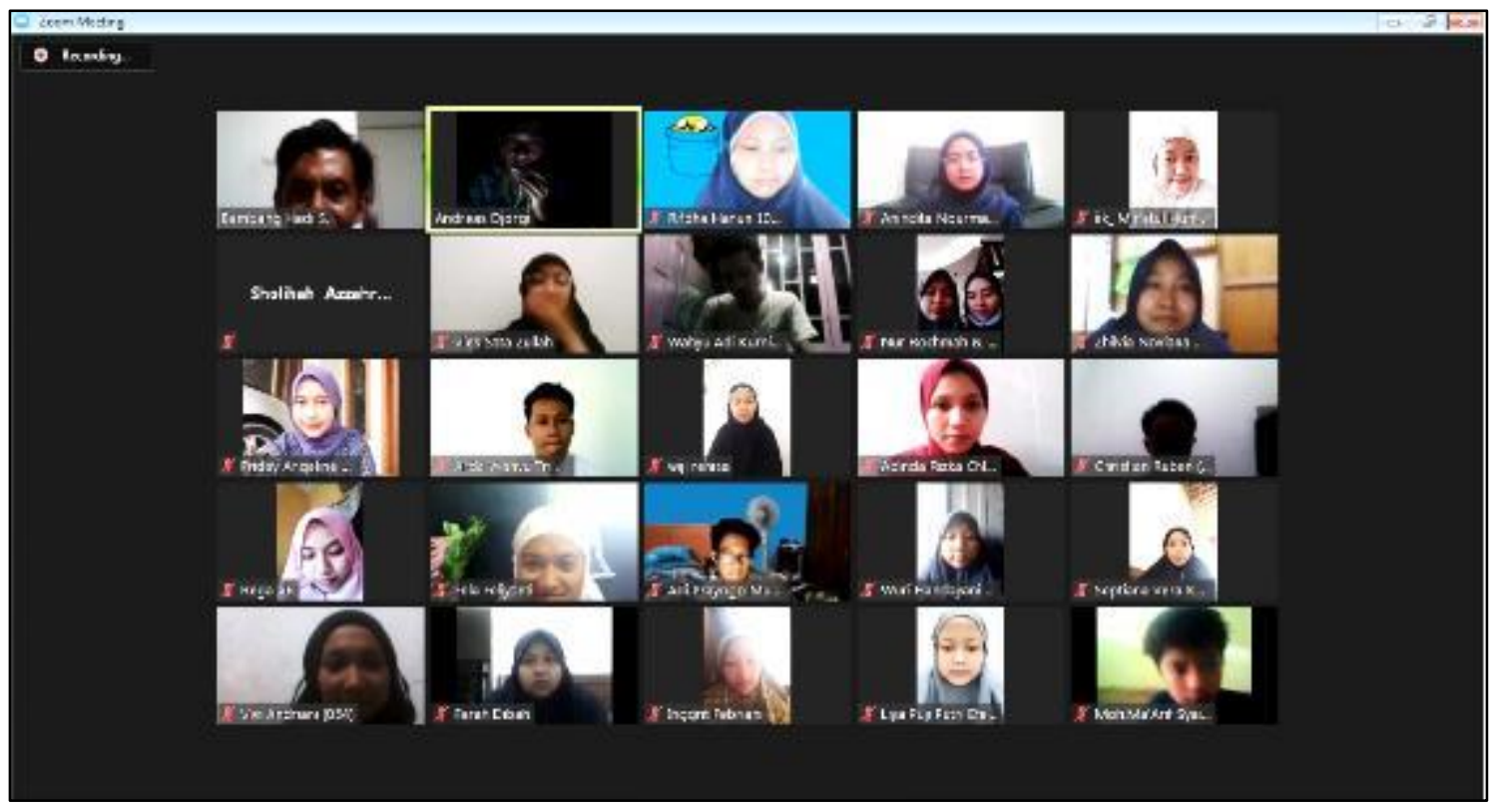

Gambar 10. Peserta Umum Seminar secara Online melalui Aplikasi Zoom (Sumber: Dokumentasi GIBEI STIESIA)

Dokumen di bawah adalah dokumen formulir aplikasi yang harus diisi oleh mahasiswa dan pelajar dalam rangka pembukaan Rekening Efek setelah mengikuti sosialisasi \& edukasi pasar modal dan investasi di pasar modal melalui GIBEI STIESIA Surabaya:

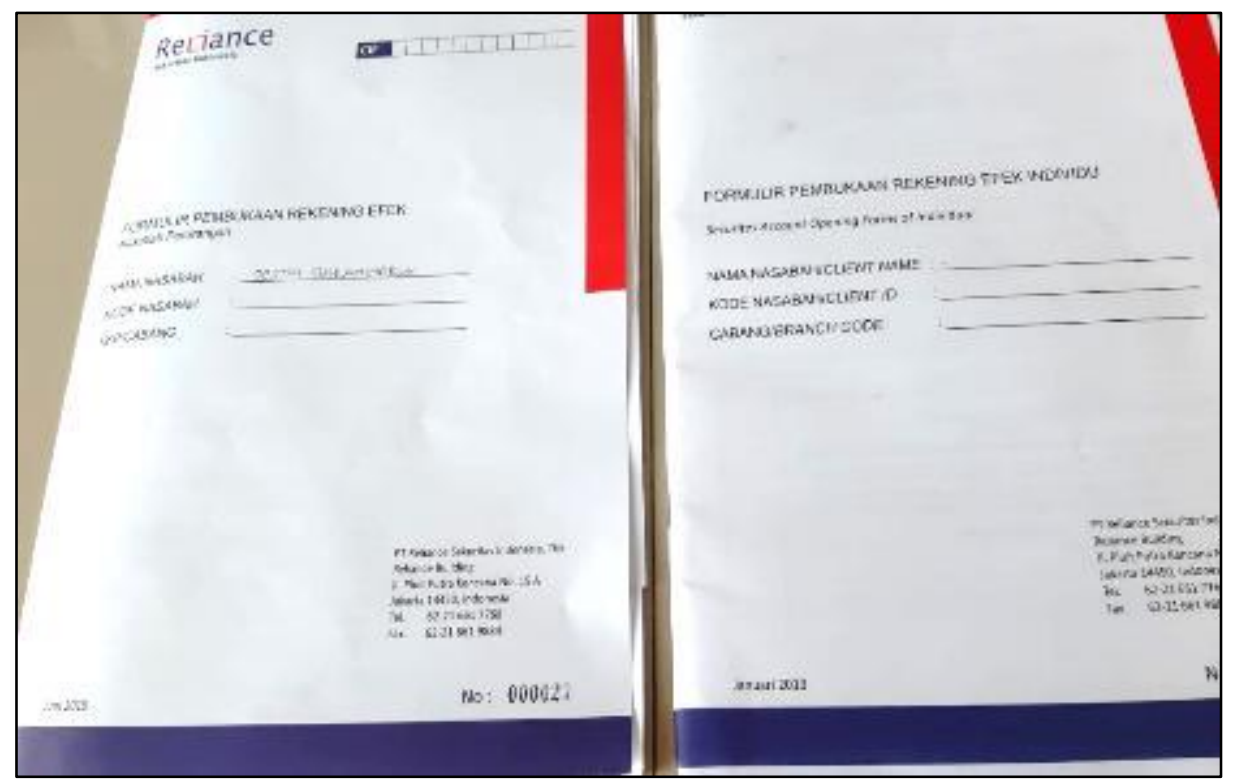

Gambar 11. Formulir Aplikasi Pembukaan Rekening Efek (Sumber: Dokumentasi GIBEI STIESIA) 
Sedangkan dokumentasi di bawah ini menggambarkan suasana pengisian aplikasi pembukaan Rekening Efek oleh para pemodal dari kalangan mahasiswa yang dipandu oleh mitra kerja bersama - sama dengan PT Reliance Securities Indonesia Tbk:

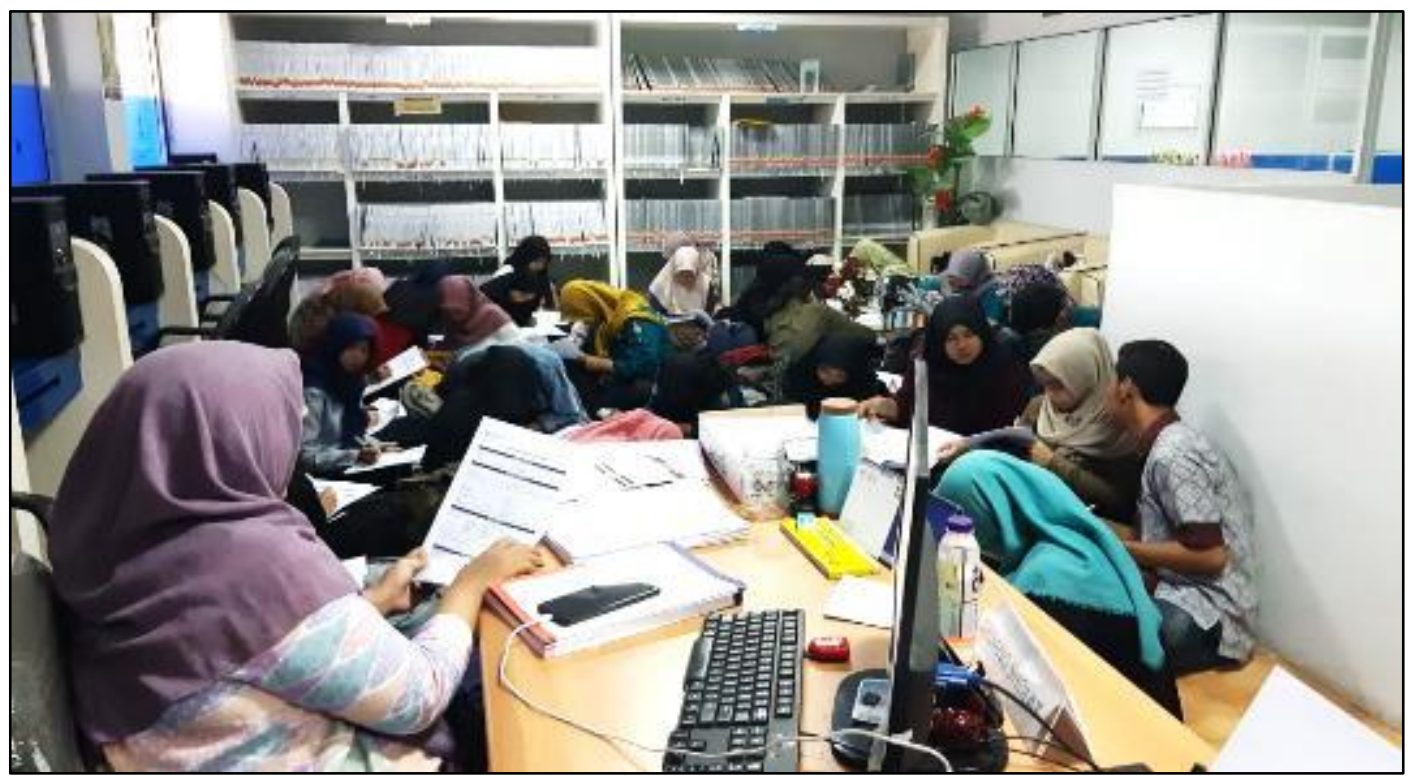

Gambar 12. Suasana Pengisian Aplikasi Pembukaan Rekekning Efek oleh Mahasiswa (Sumber: Dokumentasi GIBEI STIESIA)

\section{KESIMPULAN}

Simpulan dari hasil kegiatan pengabdian masyarakat secara singkat dapat dijelaskan sebagai berikut:

- Masyarakat dari kalangan kawula muda (mahasiswa dan pelajar) menjadi faham akan bidang pasar modal dan investasi di pasar modal sampai mereka bersedia untuk melakukan pembukaan Rekening Efek yang merupakan sarana untuk dapat berinvestasi di pasar modal.

- Mitra kerja pada akhirnya dapat lebih memberikan layanan prima kepada masyarakat kawula muda (mahasiswa dan mahasiswa) pada saat mereka melakukan pembukaan Rekening Efek setelah mereka memahami bidang keuangan pasar modal dan investasi di pasar modal serta mempunyai niatan untuk berinvestasi di pasar modal.

- Mitra kerja pada akhirnya dapat lebih memberikan layanan yang prima setelah masyarakat kawula muda (mahasiswa dan pelajar) memiliki Rekening Efek (pasca pembukaan Rekening Efek).

- Terjadi kenaikan jumlah peserta kegiatan sosialisasi \& edukasi melalui mitra kerja Galeri Investasi Bursa Efek Indonesia (GIBEI)) - Sekolah Tinggi Ilmu Ekonomi Indonesia (STIESIA) Surabaya di tahun 2019 dibandingkan dengan tahun sebelumnya.

- Terjadi penambahan nilai transaksi perdagangan efek dari bulan ke bulan selama tahun 2019, yang dengan demikian dapat meningkatkan kinerja mitra kerja (Galeri Investasi Bursa Efek Indonesia (GIBEI)) - Sekolah Tinggi Ilmu Ekonomi Indonesia (STIESIA) Surabaya.

- Adanya kenaikan nilai transaksi perdagangan efek membawa pengaruh pada kenaikan transaction fee jual maupun transaction fee beli yang diterima mitra kerja GIBEI STIESIA Surabaya dan juga PT Reliance Securities Indonesia Tbk. 


\section{DAFTAR PUSTAKA}

Badan Pusat Statistik Propinsi Jawa Timur, Jawa Timur dalam Angka 2014.

Dwidjosumarno, Bambang Hadi Santoso, Pengaruh Job Stressor dan Stock Market Conditions terhadap Performance dan Turnover Intention dengan Incentive Reward sebagai Variabel Moderasi (Studi pada Perantara Pedagang Efek Ekuitas di Surabaya, disertasi, Program Doktor Ilmu Ekonomi, Fakultas Ekonomi dan Bisnis, Universitas Airlangga, Surabaya, 2017.

Dwidjosumarno, Bambang Hadi Santoso, The Analysis of Influence of Job Stressor upon Performance and Turnover Intention of Broker - Dealer of Equity Securities Companies in Surabaya, International Journal of Scientific and Research Publications, Print Version, Volume 7, Issue 11, November 2017 Edition.

GIBEI STIESIA Surabaya, Laporan Bulanan Galeri Investasi Bursa Efek Indonesia-Sekolah Tinggi Ilmu Ekonomi Indonesia (STIESIA) Surabaya Desember 2019, Desember 2019.

GIBEI STIESIA Surabaya, Laporan Bulanan Galeri Investasi Bursa Efek Indonesia-Sekolah Tinggi Ilmu Ekonomi Indonesia (STIESIA) Surabaya Nopember 2019, Nopember 2019.

GIBEI STIESIA Surabaya, Laporan Bulanan Galeri Investasi Bursa Efek Indonesia-Sekolah Tinggi Ilmu Ekonomi Indonesia (STIESIA) Surabaya September 2019, September 2019.

GIBEI STIESIA Surabaya, Laporan Bulanan Galeri Investasi Bursa Efek Indonesia-Sekolah Tinggi Ilmu Ekonomi Indonesia (STIESIA) Surabaya Juli 2019, Juli 2019.

GIBEI STIESIA Surabaya, Laporan Bulanan Galeri Investasi Bursa Efek Indonesia-Sekolah Tinggi Ilmu Ekonomi Indonesia (STIESIA) Surabaya Juni 2019, Juni 2019.

GIBEI STIESIA Surabaya, Laporan Bulanan Galeri Investasi Bursa Efek Indonesia-Sekolah Tinggi Ilmu Ekonomi Indonesia (STIESIA) Surabaya Mei 2019, Mei 2019.

GIBEI STIESIA Surabaya, Laporan Bulanan Galeri Investasi Bursa Efek Indonesia-Sekolah Tinggi Ilmu Ekonomi Indonesia (STIESIA) Surabaya April 2019, April 2019.

GIBEI STIESIA Surabaya, Laporan Bulanan Galeri Investasi Bursa Efek Indonesia-Sekolah Tinggi Ilmu Ekonomi Indonesia (STIESIA) Surabaya Maret 2019, Maret 2019.

GIBEI STIESIA Surabaya, Laporan Bulanan Galeri Investasi Bursa Efek Indonesia-Sekolah Tinggi Ilmu Ekonomi Indonesia (STIESIA) Surabaya Pebruari 2019, Pebruari 2019. 